\title{
Glucose Metabolism Studied Isotopically in Diabetic Dogs: Effect of Restoration of Peripheral Normoinsulinaemia by the Artificial B Cell
}

\author{
E.-J. Freyse, U. Fischer and G. Albrecht \\ Central Institute of Diabetes "Gerhardt Katsch", Karlsburg, GDR
}

\begin{abstract}
Summary. Normoglycaemia, peripheral normoinsulinaemia, and normoglucagonaemia were restored acutely in chronically diabetic dogs, using an extracorporal artificial B cell with peripheral venous insulin administration. Glucose metabolism was analysed by a non-steady-state tracer technique with double-labelled glucose $\left(6-{ }^{3} \mathrm{H}-\right.$ and $\mathrm{U}-{ }^{14} \mathrm{C}-$ glucose $)$, and the incorporation of the ${ }^{14} \mathrm{C}$ label into plasma lactate was determined. In the basal state, glucose turnover rates were not different from those in non-diabetic controls; but recirculation of the glucose-C label through the Cori cycle, and lactate labelling from glucose utilization were decreased. The glycaemic response to an intravenous infusion of non-labelled glucose was distinctly enhanced. This was based on a reduction
\end{abstract}

in the rates of glucose disappearance. Its rates of appearance (total endogenous glucose production) were, however, suppressed to a normal extent by the exogenous glucose. Accordingly carbon recycling was nearly totally suppressed during the glucose infusion as in the controls. It is concluded that metabolic recompensation in these fasting, resting diabetic dogs remained incomplete because the interval of normoinsulinaemia, which obviously applied only to the peripheral circulation, was not long enough.

Key words: Diabetic dog, artificial B cell, glucose metabolism, tracer kinetics in vivo, lactate, carbon recirculation.
Several hormonal and metabolic parameters in circulating blood can be restored to normal in insulin-dependent diabetic subjects by short-term closed-loop blood glucose control for up to $24 \mathrm{~h}$ using an extracorporal artificial B cell, e.g. the fasting concentrations of ketones [1], some amino acids [17, 19], glucagon $[2,19]$ and the responses to different food or glucose stimuli $[1,2,44]$. Other metabolites, however, remain abnormal after such short-term restoration of normoglycaemia. Thus the concentrations of lactate, pyruvate [32], and alanine $[1,19]$ remain elevated, those of non-esterified fatty acids are frequently reduced $[1,2,17]$, and ketone bodies respond more intensely to feeding [44].

It is not yet clear whether the isotopically measured glucose turnover in vivo is also normalized when normoglycaemia is acutely restored in diabetes. After meals it was distinctly elevated in dogs treated with an artificial B cell [37]. But in exercising diabetic patients on the artificial B cell, the pattern of endogenous glucose production was normal [43]. However, reduced rates of recirculation of the ${ }^{14} \mathrm{C}$ label from the blood-glucose pool after meals were reported by Nosadini et al. [32]. All these studies were performed during peripheral administration of insulin, and there was always a certain degree of hyperinsulinaemia, as reported by several au- thors $[1,2,19,22]$. Peripheral normoinsulinaemia during such treatment with an extracorporal artificial B cell has been made possible by an algorithm for glucose-dependent insulin dosage based on regression analysis of the physiological glucose: peripheral plasma insulin relationship [10]. Thus the aim of this study was to analyse the degree of normalization of isotopically measured glucose turnover, of carbon recirculation, and of lactate metabolism in diabetic dogs with peripheral normoinsulinaemia restored and maintained by an artificial B cell.

\section{Material and Methods}

\author{
Animals \\ Nine diabetic Alsatian dogs (aged $34 \pm 4$ months, duration of diabetes \\ $9 \pm 2$ months, body weight $24 \pm 1 \mathrm{~kg}$ ) and nine non-diabetic dogs \\ (aged $36 \pm 4$ months, body weight $28 \pm 1 \mathrm{~kg}$ ) were studied. Three of \\ the diabetic animals had been used previously in the control study \\ before diabetes. \\ Experimental diabetes was produced by partial pancreatectomy \\ and subsequent infusion of streptozotocin into the superior pancre- \\ aticoduodenal artery as detailed by Freyse et al. [16]. Based on se- \\ quential blood glucose measurements, these animals were treated \\ with three SC injections a day of monocomponent porcine insulin
}


(dose $1.6 \pm 0.2 \mathrm{IU} \cdot \mathrm{kg}^{-1} \cdot \mathrm{day}^{-1}$ ). The total loss of endogenous B cell function was proved by canine C-peptide analyses in peripheral plasma. The animals lacked anti-insulin antibodies. Production of diabetes and animal handling have been detailed by Fischer et al. [10].

\section{Experimental Design}

The animals were well accustomed to the experimental conditions. During the tests they stood unrestrained in Pavlov frames of our own manufacture. On the morning of the experimental day, percutaneous prepared catheters were inserted (1) through a saphenous vein in the inferior caval vein for the infusions (Teflon Portex Intravenous Tubing, Hythe, Kent, UK); and (2) through a jugular vein in the superior caval vein for blood sampling (Cavafix RMT catheters, B. BraunMelsungen, Melsungen, FRG).

In addition they had an indwelling polyethylene cannula (Volkseigener Betrieb Kombinat Medizin-, Labor-und Wägetechnik, Kombinatsteil Medizinplaste, Lichtenberg, GDR) in a leg vein for glucose monitoring during the glucose-controlled insulin infusions. Perfusor E syringe pumps (B.Braun-Melsungen, Melsungen, FRG) were used for all infusions. The animals received a basal infusion of $0.5 \mathrm{ml} / \mathrm{min}$ sodium chloride $(0.154 \mathrm{~mol} / 1)$, supplemented according to protocol with the tracer solution $(0.1 \mathrm{ml} / \mathrm{min})$, with the test solution of unlabelled glucose $(1.0 \mathrm{ml} / \mathrm{min})$, and in the diabetic animals with the insulin solution $(240 \mathrm{mU} / \mathrm{ml})$. Insulin was delivered at $2.5 \mathrm{~min}$ intervals in pulses of constant rate $\left(0.1 \mathrm{ml} \cdot \mathrm{min}^{-1} \cdot \mathrm{kg}^{-1}\right)$ but of variable duration by a laboratory extracorporal artificial B cell of our own design [10]. The delay between sampling for glucose analysis and subsequent insulin dosage was $2 \mathrm{~min}$. The algorithm parameters $a_{i}$ for insulin dosage were obtained by regression analysis of normal glucose and plasma insulin data [10] according to

dose $=a_{0}+a_{1}\left(G_{t+\Delta t}-G_{b}\right)+a_{2}\left(G_{t+\Delta t}-G_{t}\right)$

where $\mathrm{G}$ is the glucose concentration, and the subscripts denote the time $\mathrm{t}$, the interval $\Delta \mathrm{t}$, and the normal fasting basal state $\mathrm{b} . \mathrm{a}_{0}$ is the basal dose which was infused during each $2.5 \mathrm{~min}$ interval. Every other interval a new dose was calculated depending on $G_{t+\Delta t}$ and $G_{t}$ and was infused in addition to $\mathrm{a}_{0}$.

\section{Infusates}

The tracer solution consisted of freshly chromatographed D-U- ${ }^{14} \mathrm{C}-$ glucose (specific activity $9.916 \mathrm{MBq} / \mathrm{mmol}$ ) and $\mathrm{D}-6-{ }^{3} \mathrm{H}$-glucose (1.369 GBq/mmol), obtained from the Radiochemical Centre, Amersham, Bucks, UK. It was diluted with $50 \mathrm{ml} \mathrm{NaCl}(0.154 \mathrm{~mol} / \mathrm{l})$ to a final concentration of $185 \mathrm{kBq} / \mathrm{ml}^{14} \mathrm{C}$ and $740 \mathrm{kBq} / \mathrm{ml}{ }^{3} \mathrm{H}$. The unlabelled glucose was diluted with sterile distilled water to give the indicated dosage referred to the body weight (average concentration $250 \mathrm{mg} / \mathrm{ml}$ ). The insulin solution contained $240 \mathrm{mU} / \mathrm{ml}$ of a shortacting monocomponent insulin (Novo Industri, Copenhagen, Denmark $)$ in $\mathrm{NaCl}(0.154 \mathrm{~mol} / \mathrm{l})$ supplemented with $10 \% \mathrm{v} / \mathrm{v}$ sterile mixed normal homologous serum. All glucose solutions were freshly prepared at the beginning of the experiment. The insulin infusate was prepared $16 \mathrm{~h}$ before the experiment.

\section{Protocol}

The diabetic animals were treated with the artificial $\mathrm{B}$ cell from $06.00 \mathrm{~h}$, i. e. $12 \mathrm{~h}$ after their last meal and last SC insulin injection. After normoglycaemia had been established, the constant tracer infusion $\left(18.5 \mathrm{kBq}{ }^{14} \mathrm{C}\right.$ - and $74 \mathrm{MBq}{ }^{3} \mathrm{H}$-glucose/min) began with a priming dose of $925 \mathrm{kBq}{ }^{14} \mathrm{C}$ - and of $3.7 \mathrm{MBq}{ }^{3} \mathrm{H}$-glucose, respectively. The control animals were identically infused but without any insulin administration. One animal of each group was not infused with doublelabelled glucose but with ${ }^{14} \mathrm{C}$-labelled glucose only.

From 150 to $330 \mathrm{~min}$ after the beginning of the tracer infusion, an IV load of unlabelled glucose $\left(56.67 \mu \mathrm{mol} \cdot \mathrm{kg}^{-1} \cdot \mathrm{min}^{-1}\right)$ was administered, followed by another control period of at least $75 \mathrm{~min}$. Insulin dosage by the artificial B cell was $0.32 \pm 0.05 \mathrm{mU} \cdot \mathrm{min}^{-1} \cdot \mathrm{kg}^{-1} \mathrm{during}$ normoglycaemia before the glucose infusion test, and $320 \pm 34 \mathrm{mU}$. $\mathrm{kg}^{-1} \cdot(180 \mathrm{~min})^{-1}$ to compensate for the glucose infusion test.

In an initial study, six diabetic animals were subjected to the tracer-kinetic experiment for $3 \mathrm{~h}$ in the untreated fasting state (i.e. subdecompensated). Only three received double-labelled glucose.

Blood samples for measurement of hormone and metabolite concentrations and specific activities were taken immediately before the tracer infusion and from $60 \mathrm{~min}$ at intervals of $15 \mathrm{~min}$ (exception: the glucagon concentration was analysed only five times during the experiment). The entire blood loss during one experiment was about $250 \mathrm{ml}$; the hematocrit was $0.39 \pm 0.08$ and $0.37 \pm 0.10$ (mean $\pm \mathrm{SD}$ ) at the beginning and at the end of the experiment, respectively.

\section{Analyses}

Aliquots of blood $(8 \mathrm{ml})$ were sampled in chilled tubes prepared with $500 \mathrm{U}$ heparin (Weddel Pharmaceuticals, London, UK). When glucagon was to be determined, an additional sample of $8 \mathrm{ml}$ blood was prepared with $100 \mathrm{U}$ heparin, $4000 \mathrm{U}$ of a proteinase inhibitor (Bayer, Leverkusen, FRG), and $200 \mathrm{ng} \mathrm{NaN}$. All samples were centrifuged immediately at $4{ }^{\circ} \mathrm{C}$ and stored at $-178^{\circ} \mathrm{C}$ until analysis. Glucose concentrations in plasma and urine (Beckman analyzer), blood total ketone bodies (measured as acetone) [29], and the immunoreactive insulin (IRI) [18] and glucagon (IRG) [42] activities in plasma were analysed. A double-antibody technique using guinea-pig anti-glucagon antiserum No.43 (Zentralinstitut für Diabetes "Gerhardt Katsch", Karlsburg, GDR) and the World Health Organization pancreatic glucagon calibration standard No.69/194 were used for the IRG assay. There was a $5 \%$ cross-reaction of the antibody used with porcine entero-glucagon-like immunoreactivity.

To calculate specific activities, the concentrations of glucose, lactate and pyruvate were determined spectrophotometrically [modified according to 3 ] in neutralized $\mathrm{HClO}_{4}$ plasma extract and in the chromatographed samples (see below) using the following substances: hexokinase (E.C. 2.7.1.1., Boehringer, Mannheim FRG), glucose-6phosphate dehydrogenase (E.C. 1.1.1.49, Ferak, West Berlin), lactate dehydrogenase (E.C. 1.1.1.27, Volkseigener Betrieb Arzneimittelwerk Dresden, GDR), NADP and $\mathrm{NADH}_{2}$ (Volkseigener Betrieb Arzneimittelwerk Dresden, GDR), ATP (Boehringer, Mannheim, FRG).

Triplicates of the ${ }^{3} \mathrm{H}$-glucose activity were determined from the extract of $1 \mathrm{ml}$ plasma with $0.2 \mathrm{ml} \mathrm{HClO}_{4}(3 \mathrm{~mol} / \mathrm{l})$. After freezing, $0.2 \mathrm{mI}$ aliquots of the supernatant were lyophilized, re-dissolved with $1 \mathrm{mI}$ distilled water, and mixed with $7 \mathrm{ml}$ Bray's scintillator fluid [5]. For the determination of the ${ }^{14} \mathrm{C}$-glucose and -lactate activities, $2.0 \mathrm{ml}$ plasma were extracted with $2.0 \mathrm{ml} \mathrm{HClO}_{4}(0.5 \mathrm{~mol} / 1)$ and neutralized with $5 \mathrm{~mol} / 1 \mathrm{~K}_{2} \mathrm{CO}_{3}$. Duplicates of $1 \mathrm{ml}$ supernatants were chromatographed on minicolumns ( $5 \mathrm{ml}$, Quick-Sep, Panchem, Kleinwallstadt, FRG) with Dowex 1X8 (200-400 mesh, Serva, Heidelberg, FRG). The glucose was eluted with $4 \mathrm{ml} 0.005 \mathrm{~mol}$ TRA-HCl buffer, $\mathrm{pH} 8.1$ [21]. After an additional rinsing with the same buffer the lactate was eluted with $12 \mathrm{ml}$ of a $1: 1$ mixture of $0.15 \mathrm{~mol} \mathrm{NH}_{4} \mathrm{Cl}$ and $0.005 \mathrm{~mol}$ borate buffer, $\mathrm{pH}$ 8.1. Lactate activity was measured after lyophilization and re-dissolution of the eluate. All activity-counting was carried out over $10 \mathrm{~min}$ using a Tricarb Scintillation Counter (Liquid Scintillation Spectrometer Model 2650 Packard, Vienna, Austria) with internal standardization. Recovery after the entire procedure was $92 \pm 1 \%$ $(n=25)$ for glucose and $75 \pm 2 \%(n=28)$ for lactate respectively. To determine the dose of labelled glucose really infused, $10 \mu 1$ of the infusate was added to $0.25 \mathrm{ml}$ fasting plasma of the same animal, deproteinized, lyophilized, re-dissolved, and counted. The effective dose resulted from the ${ }^{14} \mathrm{C}$ and ${ }^{3} \mathrm{H}$ counts and the infusion rates.

\section{Calculations}

The measured concentration patterns of glucose and lactate, and of their radioactivities were stepwise (over five subsequent values) fitted to a third order polynomial, allowing for the inhomogeneities at the 
Table 1. Metabolic parameters during the fasting steady state in normal and untreated diabetic dogs

\begin{tabular}{|c|c|c|}
\hline & $\begin{array}{l}\text { Control dogs } \\
(n=8)\end{array}$ & $\begin{array}{l}\text { Diabetic dogs } \\
(n=6)\end{array}$ \\
\hline Plasma glucose $(\mathrm{mmol} / \mathrm{l})$ & $5.18 \pm 0.16$ & $21.60 \pm 1.40^{\mathrm{a}}$ \\
\hline Plasma insulin $(\mathrm{nmol} / \mathrm{l})$ & $0.043 \pm 0.010$ & $0.013 \pm 0.007^{a, b}$ \\
\hline Plasma glucagon (nmol/1) & $0.018 \pm 0.003$ & $0.042 \pm 0.007^{\mathrm{a}, \mathrm{c}}$ \\
\hline Plasma lactate $(\mathrm{mmol} / \mathrm{l})$ & $0.56 \pm 0.07$ & $0.98 \pm 0.09^{\mathrm{a}}$ \\
\hline $\begin{array}{l}\text { Blood total ketone bodies } \\
(\mathrm{mmol} / \mathrm{l})\end{array}$ & $0.18 \pm 0.03$ & $1.37 \pm 0.30^{\mathrm{ac}}$ \\
\hline $\begin{array}{l}\mathrm{R}_{\mathrm{a}}{ }^{-14} \mathrm{C}-\text { glucose } \\
\quad\left(\mu \mathrm{mol} \cdot \mathrm{kg}^{-1} \cdot \mathrm{min}^{-1}\right)\end{array}$ & $16.33 \pm 0.94$ & $17.06 \pm 0.24(n=3)$ \\
\hline $\begin{array}{l}\mathrm{R}_{\mathrm{a}}{ }^{3}{ }^{3} \mathrm{H} \text {-glucose } \\
\quad\left(\mu \mathrm{mol} \cdot \mathrm{kg}^{-1} \cdot \mathrm{min}^{-1}\right)\end{array}$ & $25.89 \pm 2.47$ & $47.23 \pm 7.87^{\mathrm{a}}$ \\
\hline $\begin{array}{l}\text { Recirculation of the } \\
\text { C-label (\%) }\end{array}$ & \pm 3 & \pm 8 \\
\hline Lactate from glucose (\%) & \pm 7 & $\pm 0(n=3)$ \\
\hline
\end{tabular}

Results expressed as mean \pm SEM

Average of four consecutive 15 min periods when the plasma glucose concentration did not differ by $>2 \%$. Last meal and last $\mathrm{SC}$ insulin injection was administered to diabetic dogs $12 \mathrm{~h}$ before the experiment. ${ }^{\mathrm{a}} p<0.05 ;{ }^{\mathrm{b}}$ not significantly different from $0 ;{ }^{\mathrm{c}}$ one fasting value per animal only

beginning and the end of the glucose infusion test. For calculating the glucose flux rates, Steele's monocompartmental model of non-steadystate kinetics was used $[38,39]$ :

$\mathbf{R}_{\mathrm{a}}=\left[\mathrm{R}^{*}-\mathrm{p} \cdot \mathrm{V} \cdot \overline{\mathrm{G}} \cdot \Delta \mathrm{a} / \Delta \mathrm{t}\right] \cdot 1 / \overline{\mathrm{a}}$

$R_{d}=R_{a}-p \cdot V \cdot \Delta G \cdot 1 / \Delta t$

where $R_{a}, R_{d}=$ rates of glucose appearance and disappearance respectively within the assumed distribution space $\left[\mu \mathrm{mol} \cdot \mathrm{kg}^{-1} \cdot \mathrm{min}^{-1}\right]$; $\overline{\mathrm{G}}, \overline{\mathrm{a}}=$ averages of the concentration [mmol/l] and of the specific activity [disintegrations per minute $/ \mu \mathrm{mol}]=[\mathrm{DPM} / \mu \mathrm{mol}]$ of glucose during the interval $\Delta \mathrm{t}=15 \mathrm{~min} ; \Delta \mathrm{G}, \Delta \mathrm{a}=$ changes in the concentration and in the specific activity during the interval $\Delta t=15 \mathrm{~min}$; $\mathrm{R}^{*}=$ tracer dose infused [DPM $\left.\cdot \mathrm{kg}^{-1} \cdot \mathrm{min}^{-1}\right] ; \mathrm{V}=$ apparent distribution space of glucose, $200 \mathrm{ml} / \mathrm{kg}$ according to own previous observations with no difference between diabetics and controls; $p=0.65$, pool fraction of the glucose space [7,33]. The recirculation rates of the carbon level were estimated from the experiments using double-labelled glucose. It is the $\mathrm{R}_{\mathrm{a}}$-difference between the estimates from the ${ }^{14} \mathrm{C}$ - and from the ${ }^{3} \mathrm{H}$-specific activities, given as percentage of the ${ }^{3} \mathrm{H}$ glucose flux rates $[9,24,27,28]$.

Lactate labelling resulting from glucose metabolism is according to Forbath et al. [12].

Percentage lactate from glucose $=\left(\mathrm{a}_{\mathrm{lac}} \cdot 2 \cdot 100\right) / \mathrm{a}_{\text {gluc }}$

where "a" denotes the respective specific activities. All calculations were done on a C 8205 computer (Volkseigener Betrieb Cellatron, Meiningen, GDR). Results are expressed as mean \pm SEM, and the non-paired t-test $(p<0.05)$ was performed if appropriate.

\section{Results}

\section{Fasting Untreated Diabetic Animals (Table 1)}

Twelve $\mathrm{h}$ after their last meal and last $\mathrm{SC}$ insulin injection, the diabetic animals had near-zero plasma IRI concentrations and hyperglycaemia of approximately $20 \mathrm{mmol} / 1$ which remained steady for at least $4 \mathrm{~h}$. Plasma glucagon and lactate concentrations and blood acetone were also slightly but significantly increased. Under these conditions, the steady-state glucose turnover $\left(R_{a}=R_{d}\right)$ was normal from the ${ }^{14} \mathrm{C}$-glucose specific activities but considerably enhanced when estimated from the ${ }^{3} \mathrm{H}$-glucose data. This resulted in a distinct increase in rates of recirculation of the carbon moiety through the Cori cycle and in an increased labelling of the circulating lactate by glucose.

\section{Glucose Turnover on the Artificial B Cell}

Hyperglycaemia was corrected in all diabetic animals within $2-3 \mathrm{~h}$ after connection to the artificial B cell (see prototype experiment Fig.1). During the subsequent glycaemic steady state, the tracer infusions were begun. Subsequently there was also a stable glycaemic pattern

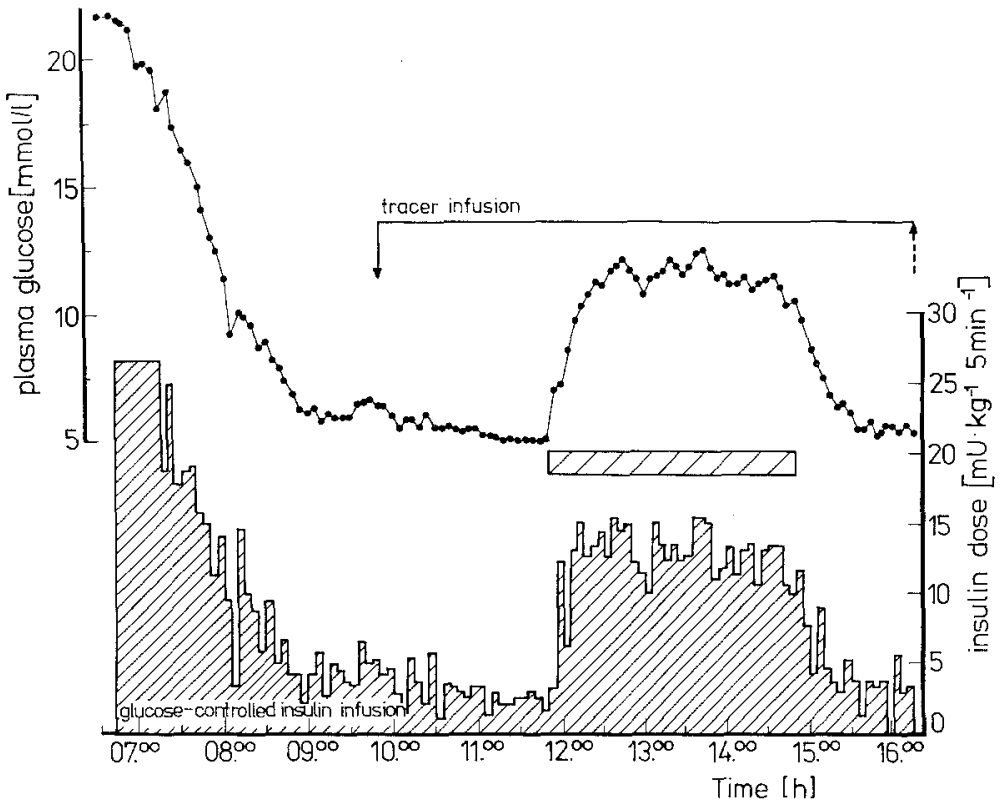

Fig. 1. Experimental protocol in a diabetic dog. Upper panel: plasma glucose concentration. Lower panel: insulin dosage by the artificial B cell $(\Delta \mathrm{t}=5 \mathrm{~min})$. Horizontal line = infusion of double labelled glucose, horizontal bar DIIIT = duration of the intravenous glucose load $\left(56.57 \mu \mathrm{mol} \cdot \mathrm{kg}^{-1} \cdot \mathrm{min}^{-1}\right)$. From $10.50 \mathrm{~h}$ blood samples were taken for the preparation of the specific activities $(\Delta \mathrm{t}=15 \mathrm{~min})$. 


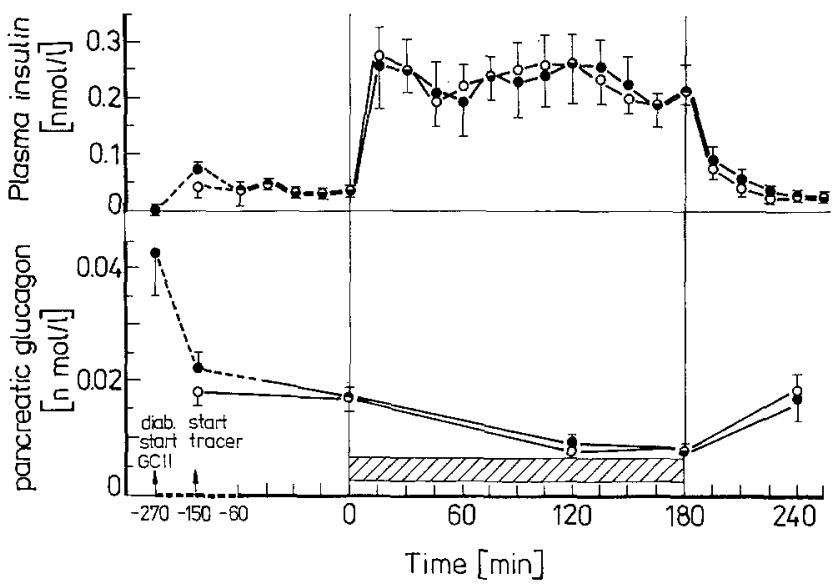

Fig. 2. Plasma insulin and pancreatic glucagon concentrations in nine control $(\mathrm{O}-\mathrm{O})$ and nine diabetic dogs $(-0)$ on the artificial B cell before, during, and after a glucose infusion test QIZIA. The mean values are identical where semicircles are presented

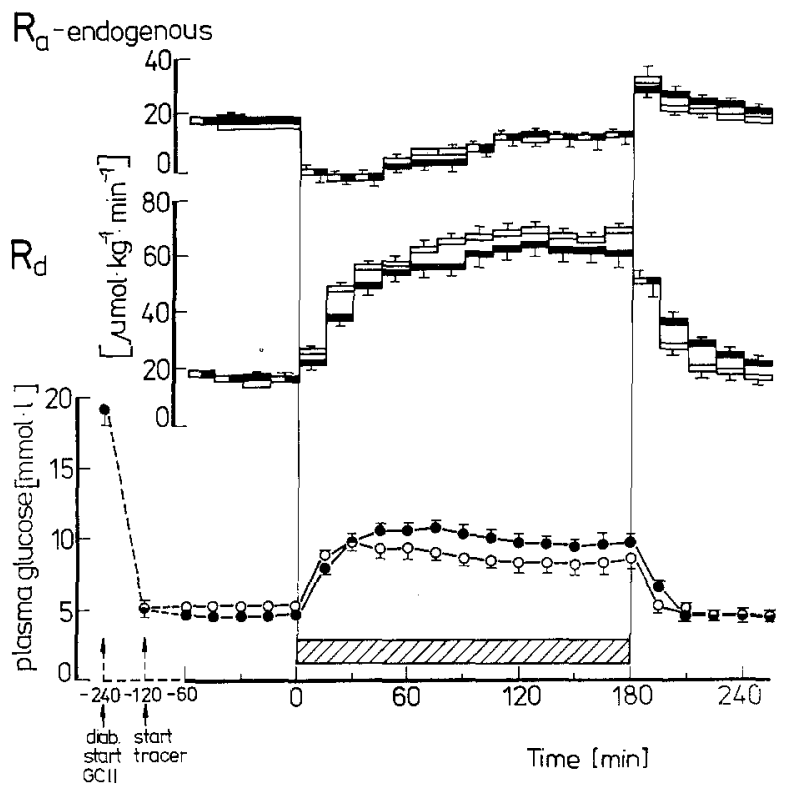

Fig. 3. Plasma glucose concentration and glucose flux rates as estimated from the specific activities of $\mathrm{U}^{14} \mathrm{C}$-glucose in nine normal $(\mathrm{O}-\mathrm{O}, \square)$ and nine diabetic dogs $(-\infty, \square)$ on the artificial $\mathrm{B}$ cell before, during and after a glucose infusion test ZIITA To show the endogenous $R_{a}$, during the infusion of unlabelled glucose, the dose $\left(56.67 \mu \mathrm{mol} \cdot \mathrm{kg}^{-1} \cdot \mathrm{min}^{-1}\right)$ was subtracted from the estimated total $R_{a}$. Mean \pm SEM, SEM is not given where smaller than the symbols. The horizontal bars denoting flux rates are smaller than $\Delta \mathrm{t}=15 \mathrm{~min}$ where the estimates for control and diabetic dogs are identical

in all experiments when unlabelled glucose was infused for $3 \mathrm{~h}$. After initial correction the plasma curves of insulin and pancreatic glucagon concentrations did not differ between the normal and diabetic animals on the artificial B cell during the entire experiment (Fig. 2).
The average glycaemia before glucose infusion test was also identical in the two groups of animals but during the steady-state phase of the exogenous parenteral glucose load, it was higher by $1-2 \mathrm{mmol} / 1$, and normalization was also delayed in the diabetic dogs on the artificial B cell (Fig. 3). Thus the integrated glycaemic response area was $985 \pm 92$ in relation to $555 \pm 61 \mathrm{mmol}$. $1^{-1} \cdot \min ^{-1}$ in the normal animals $(p<0.05)$. This difference cannot be explained by any insufficiency in the suppression of endogenous glucose production by exogenous glucose in the diabetic animals (Fig. 3). It was nearly totally suppressed between 0 and $60 \mathrm{~min}$ of the glucose infusion test in both experimental groups. From 90 min the endogenous $R_{a}$ was incompletely restored (significantly different from zero, $p<0.05$ ) and finally a new steady state was established at a low level. There was again no difference between the two groups of animals in the post-glucose infusion test rates of glucose production.

However, $R_{d}$ was slightly reduced in the diabetic animals during the glucose infusion test. It was $9.26 \pm 0.60$ in relation to $10.99 \pm 0.40 \mathrm{mmol} \cdot \mathrm{kg}^{-1} \cdot(180 \mathrm{~min})^{-1}$ during the entire test in the controls $(p<0.05)$. It was mainly the dynamics of $R_{d}$ that were altered in the diabetic dogs (Fig. 3): both the initial increase and the post-glucose infusion test decrease are delayed. The differences in glucose utilization were not caused by differences in the renal handling of glucose. Glucosuria was $37 \pm 11$ (diabetic) and $17 \pm 5 \mu \mathrm{mol} / \mathrm{kg}$ (controls) respectively during the entire experiment of at least $8 \mathrm{~h}$ (NS) and thus contributed by $<0.2 \%$ to the total glucose disappearance from its distribution space.

\section{Carbon Recirculation and Lactate Metabolism}

There was a significant reduction in the basal rate of carbon recycling through the Cori cycle in the diabetic animals appropriately supplied with insulin. This was reproduced after the glucose infusion test. It was however totally suppressed in both groups of animals (Fig.4) when endogenous glucose production was more or less inhibited during the glucose infusion test (Fig.3).

Also, the basal lactate levels were not completely restored in the diabetic animals after the short duration of initial insulin administration. Their response to the glucose infusion test was, however, normal as the reactive areas of $115 \pm 29$ (diabetics) and $92 \pm 15 \mathrm{~mol} \cdot \mathrm{l}^{-1}$. $\min ^{-1}$ (controls, NS). This applies also to the lactate: pyruvate ratios. The part of circulating lactate arising from glucose metabolism was normalized in the diabetic animals before the glucose infusion test. During the test it was only transiently diminished when the glucose utilization $R_{d}$ was distinctly reduced (Figs. 3 and 4 ). 


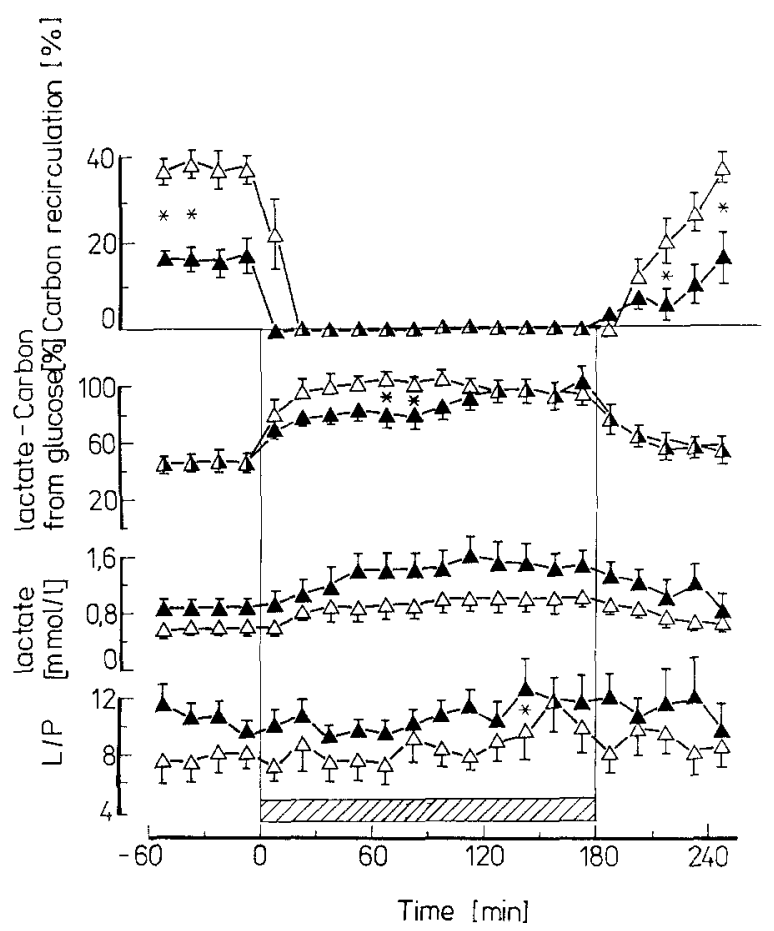

Fig.4. Percentage recirculation of the glucose carbon label $(n=8)$, percentage of circulating lactate coming from glucose $(n=9)$, plasma lactate concentration and lactate/pyruvate ratio $(\mathrm{L} / \mathrm{P})$ in normal $(\triangle-\Delta)$ and in diabetic dogs on the artificial B cell $(\Delta-\Delta)$. The mean values are identical where semi-triangles are presented. *Significant differences between the groups. During the infusion of unlabelled glucose QZII, the kinetics of $6-{ }^{3} \mathrm{H}$-glucose and of $\mathrm{U}-{ }^{14} \mathrm{C}$-glucose gave idential flux rates thus resulting in zero percentage recirculation

\section{Discussion}

There are contradictory data on the flux rates of glucose in vivo in hypoinsulinaemic diabetic dogs. Based on ${ }^{14} \mathrm{C}$-glucose data, these have been found normal [26] but experiments with tritiated glucose have usually shown elevated levels $[20,25]$. This corresponds to the results of this study: the untreated hypoinsulinaemic, hyperglucagonaemic dogs showed steady-state fasting hyperglycaemia as observed by other authors in patients [31], and they had an increased rate of appearance as calculated from the ${ }^{3} \mathrm{H}$-glucose specific activities but a normal rate of appearance as calculated from the ${ }^{14} \mathrm{C}$-glucose specific activities, thus resulting in increased recirculation rates. This resulted also in an increase of the lactate levels and of the contribution of glucose metabolism to lactate production as was similarly published by Hetenyi et al. [20].

The values for carbon recycling in healthy dogs are identical to the $40 \%$ given by DeFronzo et al. [8]. Reichard et al. [35] and Nosadini et al. [32] reported values of half that magnitude from their tracer injection experiments. Nosadini et al. [32] also showed a reduced carbon recirculation in diabetics under artificial $\mathrm{B}$ cell control. The differences may be explained by the different tracer techniques. Very similar rates of lactate carbon formation from circulating glucose were given by Kreisberg et al. [30] for human beings and Forbath and Hetenyi [12] for intact dogs. But both groups pointed to great variations due to stress sensitivity of the lactate metabolism.

The model of animal diabetes used in this study is characterized by a total lack of pancreatic insulinogenic function but by an at least partially preserved exocrine pancreatic activity [16]. According to Blazquez et al. [4] it is, however, to be expected that in dogs the effective A cell function remains near-normal after this procedure, since gastric glucagon has apparently the same biological function. Accordingly there was a certain basal hyperglucagonaemia in these animals in the morning when they needed a new insulin supply. This hyperglucagonaemia was reversed during the glucose-controlled insulin infusion.

The main part of this study was performed after acute restoration and maintenance of peripheral normoinsulinaemia. Pre-programmed insulin infusion overnight can produce euglycaemia early in the morning. But the influence of initial hyperinsulinaemia can, however, be excluded, because after the glucose infusion test the same basal metabolic situation appeared as before.

So far it is not known whether normoinsulinaemia is really important for the long-term therapeutic effect of an artificial B cell, and in general hyperinsulinaemia has been observed in short-term studies $[1,2,13,19,22$, 41].

Plasma pancreatic glucagon levels were also normalized in the animals reported here. Thus the differences observed in glucose metabolism between the control and diabetic dogs on the artificial B cell cannot be ascribed to any abnormality in peripherally available pancreatic glucoregulatory hormones. Basal glucose flux rates were also normalized in diabetic dogs under short-term artificial B cell treatment as shown by other authors $[32,37,43]$. But the recirculation of the carbon label was significantly lower than the $30 \%-40 \%$ observed in the control dogs in this study and of other investigations $[8,14,15,23,28,30,32]$. These findings and the slightly increased plasma lactate levels point to a decreased turnover of lactate. Thus the Cori cycle activity still seems to be inhibited in these resting diabetic animals, which were apparently sufficiently treated with insulin. Since the total rate of glucose utilization was essentially normal, one might speculate that the oxidative glucose metabolism and/or the formation of glycogen are relatively enhanced.

In addition, the utilization of the exogenous parenteral glucose load is also not completely normalized in these animals. On the one hand, endogenous glucose production is suppressed and finally directed to a new steady state level [24] as it is in non-diabetic controls. Accordingly, there is no recirculation of the carbon label [34]. On the other hand, the rate of disappearance shows a delayed and slightly diminished response to the 
glucose infusion and to the related insulin administration, as has similarly been found by Kalant et al. [26] in non-insulin dependent diabetic patients.

The artificial B cell algorithm parameters used in this study were estimated before the experiments by regression analysis of simultaneously measured normal peripheral venous glucose and insulin data according to formula I [10]. They were used to control the glucosedependent insulin dosage without having been individualized. The insulin dose pattern applied by the artificial B cell resulted in peripheral normoinsulinaemia but not in normal patterns of the isotopically studied glucose metabolism. One reason for this might be that the renormalization of glucose oxidation in diabetic patients is an inducible process which needs at least 3 days after connection to the artificial B cell [13].

In the experiments reported here administration of insulin into the peripheral circulation has clearly only normalized peripheral venous concentrations of insulin and glucagon. It can be assumed that there is also no normal portal-peripheral concentration gradient of insulin under these conditions since we have measured the concentration resulting both from peripheral administration and from catabolism, binding, and excretion of insulin. Thus we can expect portal venous insulin concentrations similar to those in the peripheral blood.

Thus the normal behaviour of endogenous glucose production in the diabetic animals reported on here might be explained additionally by the fact that the action of insulin on the rate of appearance is controlled by lower half-maximal plasma insulin concentrations as is its action on the rate of disappearance [36]. Accordingly, in terms of its action on the glucose disappearance rate, a certain peripheral insulin-insensitivity is to be assumed. The overall result of these conditions would be a hepatic insulinization sufficient to suppress the rate of glucose appearance to a normal extent and to reduce the lactate re-utilization to subnormal rates. But the normal peripheral insulin levels are insufficient - in this particular situation - to provide normal kinetics of utilization for an exogenous glucose load. It should be taken into consideration that the relation between hepatic and extrahepatic glucose utilization might be influenced by the route of insulin administration [40]. Thus periperhal-venous infusions, as performed in this study, allow for peripheral normoinsulinaemia but probably not for sufficient hepatic insulinization. This could have resulted both in a certain reduction of the hepatic part of the total rate of disappearance (Fig. 3) as shown by Cobelli and Ruggeri [6] employing computer techniques, of hepatic lactate utilization, and of the Cori cycle activity related to it (Fig. 4).

It has been shown by Goriya et al. [17] in a long-term study that these differences might be important in the practical application of insulin pumping systems. To achieve the same effect on the diurnal glycaemic profiles in diabetic dogs distinctly less insulin was required via portal infusion than via the peripheral route. If, on the other hand, relatively high insulin doses are administered, no differences in the food-stimulated glucose flux rates appear between the two routes of glucose administration, independently of whether insulin dosage is closed-loop-controlled [37] or open-loop-administered in identical patterns [11]. From the data presented it is concluded that glucose turnover is not restored to normal by short-term restoration of peripheral normoinsulinaemia in insulin-dependent diabetes. Intraportal insulin administration does not appear feasible with insulin pumps. Thus long-term observations are needed to determine whether complete normalization is actually necessary both in insulinaemia and glucose turnover, and - if so - whether individual adaptation of the insulin-dose parameters could compensate for the possible shortcomings of peripheral insulin administration.

Acknowledgements. This study was supported by the Research Project HFR 22 of the Ministry of Health of the German Democratic Republic. Skilful technical assistance by Mrs. K. Brüllke, Mrs. H. Schröder, Mrs. H. Buff and Miss K. Köhler is gratefully acknowledged. The radioimmunoassays were supervised by Dr. W. Besch.

\section{References}

1. Albisser AM, Goriya Y, Bahoric A, Marliss EB, Zinman B (1979) Persistent hormonal and metabolic abnormalities in spite of glucose normalization: long term studies with peripheral open-loop insulin delivery in diabetic dogs. In: Waldhäusl WK (ed) Diabetes 1979. Proceedings of the 10th International Diabetes Federation Meeting, Vienna 1979. Excerpta Medica, Amsterdam Oxford Princeton, pp 644-648

2. Albisser AM, Zinman B, Marliss EB, Botz CK (1980) The metabolic and hormonal responses to glucose infusion in anaesthetized normal and diabetic dogs controlled by an artificial B cell. Diabetologia 18: $479-485$

3. Bergmeyer HU (ed) (1970) Methoden der enzymatischen Analyse. Akademie-Verlag, Berlin, pp 1425-1429

4. Blazquez E, Munoz-Barragan L, Patton GS, Orci L, Dobbs RE, Unger RH (1976) Gastric A-cell function in insulin-deprived depancreatized dogs. Endocrinology 99: 1182-1188

5. Bray GA (1960) A simple efficient liquid scintillator for counting aqueous solutions in a liquid scintillation counter. Analyt Biochem 1: 279-285

6. Cobelli C, Ruggeri A (1983) Evaluation of portal/peripheral route and of algorithms for insulin delivery in the closed-loop control of glucose in diabetes: a modelling study. IEEE Trans Biomed Engin 30: $93-103$

7. Cowan JS, Hetenyi G (1971) Glucoregulatory responses in normal and diabetic dogs recorded by a new tracer method. Metabolism 20:360-372

8. DeFronzo RA, Jacot E, Jequier E, Maeder E, Wahren J, Felber JP (1981) The effect of insulin on the disposal of intravenous glucose. Results from indirect calorimetry and hepatic and femoral venous catheterization. Diabetes 30: 1000-1007

9. Dunn A, Chenoweth M, Schaeffer LD (1967) Estimation of glucose turnover and the Cori cycle using glucose-6-t- ${ }^{14} \mathrm{C}$. Biochemistry $6: 6-11$

10. Fischer U, Jutzi E, Bombor H, Freyse EJ, Salzsieder E, Albrecht G, Besch W, Bruns W (1980) Assessment of an algorithm for the artificial $B$ cell using the normal insulin-glucose relationship in diabetic dogs and man. Diabetologia 18:97-107 
11. Fischer U, Rizza RA, Hall LD, Westland RE, Haymond MW, Clemens AH, Gerich JE, Service FJ (1982) Comparison of peripheral versus portal venous insulin administration on postprandial metabolic responses in alloxan diabetic dogs: effects of identical preprogrammed complex insulin infusion waveforms. Diabetes 31: $579-584$

12. Forbath $\mathrm{N}$, Hetenyi G (1970) Metabolic interrelations of glucose and lactate in unanesthetized normal and diabetic dogs. Can J Physiol Pharmacol 48: 115-122

13. Foss MC, Vlachokosta FV, Cunningham LN, Aoki TT (1982) Restoration of glucose homeostasis in insulin-dependent diabetic subjects. An inducible process. Diabetes $31: 46-52$

14. Freminet A, Leclerc L, Gentil M, Poyart C (1975) Effect of fasting on the rates of lactate turnover and oxidation in rats. FEBS Lett 60: $431-434$

15. Freminet A, Poyart C, Leclerc L, Gentil M (1976) Effect of fasting on glucose recycling in rats. FEBS Lett 61:294-297

16. Freyse EJ, Hahn von Dorsche H, Fischer U (1982) Low dose streptozotocin diabetes after partial pancreatectomy in dogs. Histological findings in a new type of experimental diabetes. Acta Biol Med Germ 41: 1203-1210

17. Goriya Y, Bahoric A, Marliss EB, Zinman B, Albisser AM (1981) The metabolic and hormonal responses to a mixed meal in unrestrained pancreatectomized dogs chronically treated by portal or peripheral insulin infusion. Diabetologia 21: 58-64

18. Gottschling HD, Ziegler M, Wilke W, Michael R (1974) Radioimmunoassay von Plasmainsulin - Methodenkritische Untersuchungen. Radiobiol Radiother 15:91-97

19. Hanna AK, Zinman B, Nakhooda AF, Minuk HL, Stokes EF, Albisser AM, Leibel BS, Marliss EB (1980) Insulin, glucagon, and amino acids during glycemic control by the artificial pancreas in diabetic man. Metabolism 29: 321-332

20. Hetenyi G, Layberry RA, Foster DM, Berman M (1980) Transfer of carbon atoms among circulating glucose, alanine, and lactate in pancreatectomized dogs. Am J Physiol 239: E39-E44

21. Hofer HW (1974) Separation of glycolytic metabolites by column chromatography. Analyt Biochem 61: 54-61

22. Horwitz DL (1979) Insulin responses to mixed meals: comparison of an artificial beta cell and normal beta cells. Horm Metab Res 8 (Suppl): 68-71

23. Issekutz B (1977) Studies on hepatic glucose cycles in normal and methylprednisolone-treated dogs. Metabolism 26:157-170

24. Issekutz TB, Issekutz B, Elahi D (1974) Estimation of hepatic glucose output in non-steady state. The simultaneous use of $2-{ }^{3} \mathrm{H}-\mathrm{glu}-$ cose and ${ }^{14} \mathrm{C}$-glucose in the dog. Can J Physiol Pharmacol 52: $215-224$

25. Issekutz B, Shaw WAS (1975) Glucose turnover in the exercising dog with chemically induced diabetes and the effect of methylprednisolone. Diabetes 24:915-921

26. Kalant N, Csorba TR, Heller N (1963) Effect of insulin on glucose production and utilization in diabetes. Metabolism 12:1100-1111

27. Katz J, Dunn A (1967) Glucose-2-t as a tracer for glucose metabolism. Biochemistry $6: 1-5$

28. Katz J, Dunn A, Chenoweth M, Golden S (1974) Determination of synthesis, recycling and body mass of glucose in rats and rabbits in vivo with ${ }^{3} \mathrm{H}$ - and ${ }^{14} \mathrm{C}$-labelled glucose. Biochem $\mathrm{J} 142: 171-183$

29. Krainick HG (1938) Bestimmung der Ketonkörper in kleinen Blutmengen. Klin Wochenschr 17: 450-451

30. Kreisberg RA, Siegal AM, Owen WC (1971) Glucose-lactate interrelationships: effect of ethanol. J Clin Invest 50:175-185
31. Miles JM, Rizza RA, Haymond MW, Gerich JE (1980) Effects of acute insulin deficiency on glucose and ketone body turnover in man. Evidence for the primacy of overproduction of glucose and ketone bodies in the genesis of diabetic ketoacidosis. Diabetes 29: 926-930

32. Nosadini R, Noy GA, Nattrass M, Alberti KGMM, Johnston DG, Home PD, Ørskov H (1982) The metabolic and hormonal response to acute normoglycaemia in Type 1 (insulin-dependent) diabetes: studies with a glucose controlled insulin infusion system (artificial endocrine pancreas). Diabetologia 23: 220-228

33. Radziuk J, Norwich KH, Vranic M (1974) Measurement and validation of non steady turnover rates with application to the insulin and glucose system. Fed Proc 33: 1855-1864

34. Radziuk J, Vranic M (1977) Estimating rapid changes in the rates of glucose production from glucogenolysis and recycling through lactate. Fed Proc 36: 236-238

35. Reichard GA jr, Moury NF jr, Hahella NJ, Patterson AL, Weinhouse S (1968) Quantitative estimation of the Cori cycle in the human. J Biol Chem 238: 495-501

36. Rizza RA, Mandarino LJ, Gerich JE (1981) Dose-response characteristics for effects of insulin on production and utilization of glucose in man. Am J Physiol 240: E630-E639

37. Rizza RA, Westland RE, Hall LD, Patton J, Haymond MW, Gerich JE, Service FJ (1981) Peripheral versus portal venous administration of insulin on postprandial hyperglycemia and glucose turnover in alloxan diabetic dogs. Mayo Clin Proc 56: 434-438

38. Steele R (1959) Influence of glucose loading and of injected insulin on hepatic glucose output. Ann NY Acad Sci 82: 420-430

39. Steele R, Wall JS, de Bodo RC, Altszuler N (1956) Measurement of size and turnover rate of body glucose pool by the isotope dilution method. Am J Physiol 187: 15-24

40. Tiran J, Yamasaki Y, Albisser AM (1981) A model study of canine glucose and insulin dynamics. In: Cobelli C, Bergman RN (eds) Carbohydrate metabolism: quantitative physiology and mathematical modelling. Proceedings of an International Symposium, Padova 1979. Wiley, Chichester, pp 329-347

41. Topic E, Granic M, Stavljenic A, Skrabalo Z (1979) Intermediary metabolism over 24 hours in diabetic patients during the treatment with artificial pancreas. Diab Croatica 8: 343-354

42. Ziegler M, Wilke W, Kohnert KD, Klatt D (1975) Spezifischer Radioimmunoassay für Pankreasglukagon im Blut. In: Bibergeil $\mathrm{H}$, Fiedler H, Poser U (eds) Frühdiabetes: Pathogenese, Diagnose, Prävention. Proceedings of the 8th Symposium, Karlsburg 1974, pp 413-416

43. Zinman B, Murray FT, Vranic M, Albisser AM, Leibel BS, McClean PA, Marliss EB (1977) Glucoregulation during moderate exercise in insulin treated diabetics. $\mathbf{J}$ Clin Endocr Metab 45: $641-652$

44. Zinman B, Stokes EF, Albisser AM, Hanna AK, Minuk HL, Stein AN, Leibel BS, Marliss EB (1979) The metabolic response to glycemic control by the artificial pancreas in diabetic man. Metabolism 28: 511-517

Received: 15 September 1982

and in revised form: 27 March 1983

Dr. Ernst-Joachim Freyse

Central Institute of Diabetes

DDR-2201 Karlsburg

GDR 